\title{
Pengaruh Perubahaan ROA, Perubahan OPM, Leverage dan Ukuran Perusahaan Pada Praktik Perataan Laba
}

\author{
Ni Luh Made Sutaryani ${ }^{1}$ \\ Made Sadha Suardikha ${ }^{2}$ \\ ${ }^{1}$ Fakultas Ekonomi dan Bisnis Universitas Udayana (Unud), Bali, Indonesia \\ email : sutaryanimade@gmail.com/telp: +62 82236341355 \\ ${ }^{2}$ Fakultas Ekonomi dan Bisnis Universitas Udayana (Unud), Bali, Indonesia
}

\begin{abstract}
ABSTRAK
Adapun tujuan dari penelitian ini adalah untuk dapat mengetahui pengaruh perubahan Return On Asset (ROA), Operating Profit Margin (OPM), Ukuran perusahaan dan leverage terhadap praktik perataan laba. Lokasi dalam penelitian ini adalah perusahaan manufaktur yang terdaftar di BEI dengan objek penelitian yaitu praktik perataan laba dan unsur - unsur yang mempengaruhi laba. Jumlah populasi 158 perusahaan dengan regresi logistik sebagai metode penelitian yang digunakan dalam penelitian ini. Hasil dari penelitian ini adalah ROA, OPM dan leverage tidak berpengaruh terhadap praktik perataan laba sedangkan ukuran perusahaan berpengaruh terhadap Praktik perataan laba secara signifikan.
\end{abstract}

Kata kunci: Perataan laba, ROA, Return On Asset, OPM

\begin{abstract}
The purpose of this study is to be able to determine the effect of changes in ROA, OPM, company size and leverage to the practice of income smoothing. Locations in this study are manufacturing companies listed on the Stock Exchange with the object of research is the practice of income smoothing and elements - elements that affect earnings. The population of 158 companies with logistic regression as the research method used in this study. The result of this research is ROA, OPM and leverage have no effect to the practice of income smoothing while firm size have an effect on Practice income smoothing significantly.
\end{abstract}

Keywords: income smoothing, ROA, Return On Asset, OPM.

\section{PENDAHULUAN}

Perataan laba merupakan metode yang dipakai manajemen untuk mengurangi fluktuasi laba yang dilaporkan agar sesuai dengan target yang diinginkan perusahaan. Praktik perataan laba dipengaruhi oleh konflik kepentingan antara manajemen (agent) dan pemilik (principal) ketika semua pihak berusaha untuk mencapai dan mempertahankan tingkat kemakmuran yang dikehendakinya. 
Ni Luh Made Sutaryani dan Made Sadha Suardikha. Pengaruh...

Sasaran utamanya adalah untuk melunakkan variabilitas laba setiap tahunnya, dengan mengalihkan pendapatan dari tahun yang baik ke tahun yang buruk. Dalam hal ini pendapatan masa yang akan datang dapat dialihkan ke tahun sekarang atau sebaliknya. Demikian pula halnya, dengan biaya dapat dimodifikasi dengan mengalihkan beban atau kerugian dari periode ke periode. Ketatnya persaingan dalam dunia usaha atau bisnis menjadi pemicu yang kuat bagi manajemen perusahaan untuk menampilkan performa terbaik bagi perusahaan yang dipimpinnya. Karena baik buruknya performa perusahaan akan berdampak terhadap nilai pasar perusahaan di pasar dan juga mempengaruhi minat investor untuk menanam atau menarik investasinya dari sebuah perusahaan.

Selain hal tersebut, manajemen juga memiliki tanggung jawab untuk menyajikan laporan keuangan untuk pihak - pihak yang berkepentingan dengan laporan keuangan perusahaan, baik pihak internal maupun pihak eksternal. Laporan keuangan merupakan sarana komunikasi yang berguna sebagai penghubung pihak-pihak yang berkepentingan terhadap perusahaan, baik pihak internal (manajemen) maupun pihak eksternal (pemegang saham, kreditur, pemerintah, dan sebagainya). Laba merupakan salah satu informasi potensial yang terkandung di dalam laporan keuangan yang sangat penting bagi pihak internal maupun eksternal. Informasi laba merupakan komponen laporan keuangan perusahaan yang bertujuan untuk menilai kinerja manajemen,membantu mengestimasi kemampuan laba yang representatif dalam jangka panjang dan menaksir resiko investasi atau meminjamkan dana (Kirschen Heiter dan Melumad 2002 dalam Juniarti 2005:148). 
Pentingnya informasi laba ini disadari oleh manajemen, sehingga manajemen cenderung melakukan disfungtional behaviour (perilaku tidak semestinya), yaitu dengan melakukan perataan laba untuk mengatasi berbagai konflik yang timbul antara manajemen dengan berbagai pihak yang berkepentingan dengan perusahaan (Sugiarto, 2003). Disfungtional behaviour tersebut dipengaruhi oleh adanya asimetri informasi (information asymetry) dalam konsep teori keagenan (agency teori). Teori keagenan (agency theory) menyatakan manajemen memiliki informasi yang lebih banyak mengenai perusahaan dibandingkan pemilik perusahaan yang sering terdorong untuk melakukan tindakan yang dapat memaksimalkan keuntungan dirinya sendiri (disfunctional behaviour) dan atau perusahaannya. Kesenjangan informasi antara pihak manajemen dengan pihak yang berkepentingan lain menyebabkan memicu munculnya perataan laba.

Ashari et.al (1994) mengungkapkan bahwa perusahaan manufaktur lebih cenderung melakukan praktik perataan laba.Oleh karena hal tersebut peneliti menggunapan perusahaan manufaktur sebagai populasi penelitian.adapun perusahaan manupaktur yang terdaftar di Bursa Efek Indonesia yang telah di dipilih berdasarkan karakteristik tertentu dapat dilihat pada Tabel 1. sebagai berikut. 
Tabel 1.

Proses Pemilihan Sampel

\begin{tabular}{clc}
\hline No & Keterangan & $\begin{array}{c}\text { Jumlah } \\
\text { Perusahaan }\end{array}$ \\
\hline 1 & Perusahaan manufaktur yang terdaftar di BEI & 222 \\
2 & $\begin{array}{l}\text { Tidak memiliki laporan keuangan yang telah diaudit yang } \\
\text { berakhir pada 31 Desember }\end{array}$ & $(46)$ \\
3 & $\begin{array}{l}\text { Melakukan restrukturisasi, akuisisi, merger, dan perubahan } \\
\text { kelompok usaha }\end{array}$ & 158 \\
& Jumlah sampel yang dipakai dalam penelitian
\end{tabular}

Melalui Tabel 1.tersebut dapat diperoleh informasi jumlah perusahaan manufaktur yang terdaftar di BEI adalah 222 perusahaan. Perusahaan yang tidak mempunyai laporan keuangan yang telah diaudit per 31 desember adalah 46 perusahaan.Dan perusahaan yang melakukan restrukturisasi, akuisisi, merger dan perusahaan kelompok usaha adalah sejumlah 18 perusahaan.Sehingga perusahaan yang digunakan dalam penelitian ini adalah 158 perusahaan manufaktur.

Praktik perataan laba(income smoothing) sudah umum dilakukan, namun jika dilakukan dengan sengaja dan dibuat - buat maka akan menimbulkan informasi yang tidak memadai bagi invenstor. Sehingga investor tidak akan mendapatkan informasi yang akurat mengenai laba perusahaan untuk mengevaluasi hasil dan risiko dari portofolio mereka. penelitian mengenai perataan laba telah banyak dilakukan, namun setiap penelitian masih menunjukan hasil yang berbeda - beda. Ashari dkk. (1994), Jatiningrum (2000) dan Kumaladewi (2010) membuktikan bahwa Return On Asset (ROA) berpengaruh terhadap praktik perataan laba. Sebaliknya, hasil penelitian Jin dan Machfoedz (1998), Suwito dan Herawaty (2005) dan Syahriana (2006) memberikan hasil bahwa ROA tidak berpengaruh terhadap praktik perataan laba. 
Hasil penelitian yang dilakukan oleh Moses (1987) dalam Kumaladewi (2010), Budiasih (2006), Budhijono (2006) dan Dewi (2011) menyebutkan bahwa ukuran perusahaan berpengaruh terhadap praktik perataan laba. Sedangkan, hasil penelitian Juniarti dan Corolina (2005) memberikan hasil bahwa ukuran perusahaan tidak berpengaruh terhadap praktik perataan laba. Ada pula beberapa penelitian yang menyertakan leverage kedalam penelitianya sebagai salah satu variabel yang diteliti. Misal penelitian yang dilakukan oleh Dewi (2011), Budiasih (2006) dan Budhijono (2006) memasukan leverage sebagai salah satu variabelnya, penelitian tersebut memberikan hasil bahwa leverage tidak berpengaruh terhadap perataan laba. Berbeda halnya dengan penelitian yang dilakukan oleh Yusuf dan Soraya (2004) yang menunjukan hasil bahwa leverage berpengaruh terhadap perataan laba.

Dalam penelitian mengenai perataan laba, Operating Profit Margin (OPM) masih jarang dimasukan sebagai salah satu variabelnya. Dua penelitian yang memasukkan OPM menjadi salah satu variabelnya adalah penelitian dari Syahriana (2006) dan Kumaladewi (2010) yang nunjukan hasil bahwa OPM berpengaruh terhadap perataan laba. Penelitan ini bertujuan untuk mengindikasikan pengaruh perubahaan ROA, OPM, Ukuran perusahaan dan leverage terhadap praktik perataan laba Penelitian mencoba membahas beberapa faktor yang diduga mempengaruhi perataan laba yaitu, Perubahan ROA, Perubahan OPM, Ukuran Perusahaan dan Leverage. Selain dari itu penelitian dimotivasi oleh penelitian sebelumnya menunjukan adanya ketidak konsistenan hasil yang diperoleh. 


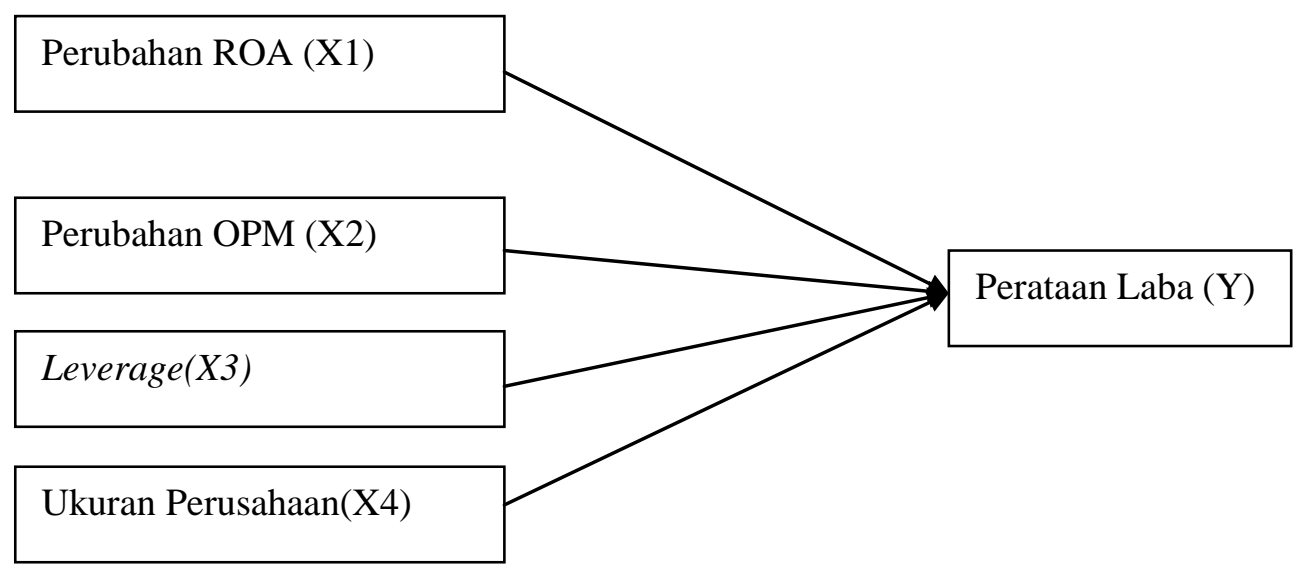

\section{Gambar 1. Kerangka Konseptual}

ROA merupakan rasio untuk mengukur kemampuan manajemen dalam menghasilkan pendapatan dari pengelolaan aset (Abdul Halim dan Mamduh, 2003:160). Semakin tinggi rasio ini berarti perusahaan semakin efektif dalam memanfaatkan aktiva untuk menghasilkan laba bersih setelah pajak. Dengan demikian dapat disimpulkan bahwa semakin tinggi ROAberarti kinerja perusahaan semakin efektif, karena tingkat kembalian akan semakin besar (Brigham, 2001:90). Dalam kaitannya dengan penelitian ini, perubahan ROA dalam sebuah perusahaan mencerminkan perubahan kemampuan manajemen dalam menghasilkan laba dengan memanfaatkan aktiva yang ditanamkan dalam sebuah perusahaan.

Semakin besar perubahan ROA dalam sebuah perusahaan menunjukan semakin meningkat juga keefektifan dari perusahaan dalam menghasilkan laba dengan mengelola asset yang dimiliki oleh perusahaan (Kumaladewi, 2010). Hal ini akan mempengaruhi perhitungan investor dalam memprediksi laba dan risiko yang mungkin dihadapi yang kemudian juga akan mempengaruhi kepercayaan investor terhadap perusahaan. Dengan demikian terjadi konflik kepentingan 
dimana manajemen termotivasi untuk melakukan perataan laba sehingga laba yang dilaporkan tidak mengalami fluktuasi.Hal ini akan menanamkan kepercayaan investor terhadap perusahaan.

Penjelasan diatas memberi pemahaman bahwa semakin tinggi perubahaan ROA semakin tinggi pula kemungkinan manajemen melakukan praktik perataan laba. Sehingga hipotesis yang dikemukakan adalah sebagai berikut:

$\mathrm{H}_{1}$ : Perubahaan ROAberpengaruh terhadap praktik perataan laba

OPM berfungsi untuk mengukur rasio laba operasi yang dicapai dibandingkan dengan penjualan bersih ( Wigustini, 2010:81). Rasio ini sering disebut juga sebagai pure profit dalam arti bahwa profit yang dihasilkan benarbenar murni dari hasil operasi perusahaan sebelum diperhitungkan dengan kewajiban lainnya (Abdullah, 2005:55). Dalam kaitannya dengan penelitian ini, perubahan OPM menunjukan perubahan kemampuan perusahaan untuk menghasilkan laba dalam kaitannya dengan kegiatan rutin perusahaan. Semakin tinggi tingkat perubahaan OPM akan menunjukan semakin tinggi pula fluktuasi kemampuan perusahaan dalam menghasilkan laba. (Kumaladewi, 2010).

Hal ini akan mempengaruhi investor dalam memprediksi kelangsungan perusahaan dan mengurangi kepercayaan investor terhadap perusahaan. Dengan demikian manajemen sebagai agent yang memiliki akses lebih banyak terhadap informasi perusahaan yang berkaitan dengan laba memiliki alasan untuk melakukan pratik perataan laba, sehingga laba perusahaan akan lebih stabil. Sehingga hipotesis penelitian berikutnya yang dikemukakan adalah sebagai berikut: 
Ni Luh Made Sutaryani dan Made Sadha Suardikha. Pengaruh...

$\mathrm{H}_{2}$ : Perubahaan OPM berpengaruh terhadap praktik perataan laba

Dalam Hipotesis Hutang/Ekuitas (Debt/Equity Hypothesis) disebutkan dalam sebagian besar perjanjian hutang terdapat syarat-syarat (covenants) yang harus dipenuhi perusahaan selama masa perjanjian. Dinyatakan pula ketika perusahaan mulai mendekati terjadinya pelanggaran terhadap debt covenant, maka manajer perusahaan akan berusaha untuk menghindari terjadinya debt covenant tersebut dengan memilih metode-metode akuntansi yang dapat meningkatkan laba. Leverage merupakan rasio antara total kewajiban dengan total aset. Semakin besar rasio leverage, berarti semakin tinggi nilai utang perusahaan. Watts dan Zimmerman (1990) menyatakan bahwa manajer di perusahaan yang berhutang kemungkinan meningkatkan laba yang dilaporkan untuk meningkatkan daya tawar perusahaan dalam negosiasi hutang, mengurangi kekhawatiran kreditur dan untuk mendapat kelonggaran batas kredit. Dengan demikian hipotesis selanjutnya adalah sebagai berikut:

$\mathrm{H}_{3}$ : Leverage berpengaruh terhadap praktik perataan laba.

Perataan laba dilakukan untuk membuat laba yang dilaporkan lebih stabil karena hal tersebut akan mempengaruhi keputusan investor untuk menginvestasikan dananya. Semakin besar ukuran perusahaan maka semakin besar pula kemungkinan manajemen melakukan praktik perataan laba (Kumaladewi, 2010). Maka hipotesis selanjutnya dalam penelitian ini adalah sebagai berikut:

$\mathrm{H}_{4}$ : Ukuran perusahaan berpengaruh terhadap praktik perataan laba. 


\section{METODE PENELITIAN}

Penelitian ini berlokasi di Bursa Efek Indonesia (BEI) yang dilakukan dengan mengakses situs resmi Bursa Efek Indonesia yaitu www.idx.co.id dan mengakses Indonesian Capital Market Directory (ICMD). Hal ini karena sampel yang digunakan dalam penelitian ini adalah perusahaan manufaktur yang terdaftar di Bursa Efek Indonesia yang laporan keuangannya dipublikasikan.Dengan tujuan untuk menganalisis pengaruh ROA, OPM, Ukuran perusahaan dan Leverage pada praktik perataan laba.

Definisi Operasional Variabel: PertamaROA merupakan rasio yang menunjukan kemampuan perusahaan dalam menghasilkan laba dengan memanfaatkan asset dalam melakukan kegiatan operasi perusahaan. ROA diukur dengan rasio antara Earning After Tax (EAT) dengan Average Total Assets (Wiagustini, 2010):

$$
\mathrm{ROA}=\frac{\text { Earning After Tax }}{\text { Average Total Assets }} \times 100 \%
$$

Kedua, OPM menunjukkan perubahan kemampuan manajemen untuk menghasilkan laba operasi dalam kegiatan rutin perusahaan. OPM diukur dengan rasio antara laba operasi dengan penjualan bersih (Wiagustini, 2010):

$$
\mathrm{OPM}=\frac{\text { Laba Operasi }}{\text { Penjualan Bersih }} \times 100 \%
$$

Ketiga, Leverage menunjukan seberapa besar asset perusahaan diperoleh dari utang. Variabel ini diukur dengan membagi total utang dengan total asset yang dimiliki perusahaan (Wiagustini, 2010):

$$
\mathrm{LEV}=\underline{\text { total utang perusahaan }} \quad \mathrm{x} 100 \%
$$


Ni Luh Made Sutaryani dan Made Sadha Suardikha. Pengaruh...

Total asset yang dimiliki perusahaan

Keempat, Ukuran perusahaan merupakan skala yang digunakan untuk mengukur besar atau kecilnya suatu perusahaan. Untuk menentukan skala tersebut harus dihitung menggunkan logaritma dari total asset yang dimiliki oleh perusahaan (Wiagustini, 2010) Maka rumus dari ukuran perusahaan adalah sebagai berikut:

Ukuran Perusahaan $=$ Ln TA

Keterangan :

Ln TA : Log natural total aset

Kelima, Status perataan laba adalah status perusahaan di mana suatu perusahaan diindikasikan sebagai perusahaan yang melakukan praktik perataan laba atau perusahaan yang tidak melakukan praktik perataan laba. Indikator perataan laba yang digunakan adalah indeks Eckel (1981). Perhitungan indeks Eckel dilakukan untuk mengetahui jumlah perusahaan yang melakukan praktik perataan laba dan tidak melakukan praktik perataan laba.

$$
\text { Indeks Eckel }=\frac{C V \Delta \mathrm{I}}{C V \Delta S}
$$

Penelitian ini menggunakan data sekunder, yaitu data yang diperoleh dalam bentuk yang sudah jadi, sudah dikumpulkan dan diolah oleh pihak lain (Sugiyono, 2007:129). Data sekunder dalam penelitian ini adalah data yang diperoleh dari Indonesian Capital Market Directory (ICMD) dan situs resmi BEI berupa laporan keuangan perusahaan sampel selama periode amatan.Perusahaanperusahaan dari sektor manufaktur digunakan berdasarkan hasil penelitian 
Jatiningrum (2000) yang mengungkapkan bahwa perusahaan yang banyak melakukan perataan laba adalah perusahaan dari sektor manufaktur.

Populasi penelitian ini adalah perusahaan - perusahaan manufaktur yang terdaftar di Bursa Efek Indonesia periode tahun 2008 - 2011.Sampel penelitian dipilih menggunakan purposive sampling method.Purposive sampling method adalah pemilihan sampel atas dasar kesesuaian antar karakteristik sampel dengan kriteria pemilihan tertentu (Sugiyono, 2007:61).

Metode pengumpulan data dalam penelitian ini adalah dengan metode observasi non participant, yaitu observasi yang dilakukan tanpa melibatkan diri atau menjadi bagian dalam lingkungan sosial atau perusahaan dan hanya menjadi pengumpul data.Dalam observasi non participant peneliti tidak terlibat dan hanya sebagai pengamat independen. Data dikumpulkan dengan cara mengamati, mencatat, serta mempelajari buku - buku dan catatan - catatan yang berkaitan dengan penelitianyang dilakukan (Sugiyono, 2007:61)

Seperti yang dinyatakan Ghozali (2011:19) bahwa tujuan statisktik deskriptif adalah untuk memberi gambaran suatu data yang dilihat dari rata-rata, standard deviasi, variance, maksimal, minimal, kurtois dan skewness (kemencengan distribusi).Pengujian hipotesis dilakukan dengan menggunakan regresi logistik karena variabel terikatnya merupakan data kualitatif yang menggunakan variabel dummy (Sumodiningrat, 2001:359, dalam Rudyawan, 2008). Teknik analisis dengan regresi logistik tidak memerlukan lagi uji normalitas pada variabel bebasnya (Ghozali, 2011:348) dan mengabaikan 
Ni Luh Made Sutaryani dan Made Sadha Suardikha. Pengaruh...

heteroskedastisitas. Analisis regresi logistik dilakukan dengan bantuan program SPSS.

\section{HASIL DAN PEMBAHASAN}

Berdasarkan Tabel 2 dapat dijelaskan hasilnya bahwa nilai ROA berkisaran antara nilai minimum -671,000 sampai dengan nilai maksimum 269,714 dengan nilai rata rata $-0,90157$ dan standar deviasi sebesar 34,338760 . Nilai minimum yang bernilai negatif berarti terdapat perusahaan dengan kondisi rugi apabila dilihat dari nilai laba sebelum dilakukan perataan laba yang terdapat dalam sampel.Nilai OPM berkisar antara nilai minimum $-87,667$ sampai dengan nilai maksimum 143,600 dengan nilai rata 0,22009 dan standar deviasi 7,551463. Nilai leverage berkisar antara nilai minimum -14,11 sampai dengan nilai maksimum 15,75 dengan standar deviasi 1,04564.

Sedangkan nilai rata - rata adalah sebesar 0,6424 hal ini menunjukan bahwa rata - rata 64,24\% asset perusahaan sampel dibiayai oleh utang.Rata - rata nilai aktiva perusahaan sampel sebesar 13,82081 (log juta rupiah) dengan niaistandar deviasi sebesar 1,955959. Nilai rata - rata dari perataan laba adalah sebesar 0,5563 yang lebih besar dari 0,50. Hal ini menunjukan rata - rata perusahaan sampel melakukan perataan laba. 
Tabel 2.

Statistik Deskriptif Sampel Penelitian

\begin{tabular}{lrrrrr}
\hline & N & Minimum & Maximum & \multicolumn{1}{c}{ Mean } & Std. Deviation \\
\hline ROA & 631 & -671.000 & 269.714 & -.90157 & 34.338760 \\
OPM & 631 & -87.667 & 143.600 & .22009 & 7.551463 \\
LEV & 631 & -14.11 & 15.75 & .6424 & 1.04564 \\
UP & 631 & 2.809 & 18.849 & 13.82081 & 1.955959 \\
INS & 631 & .00 & 1.00 & .5563 & .49722 \\
Valid N (listwise) & 631 & & & & \\
Sumber : Data diolah, 2017 & & & &
\end{tabular}

Tabel 3.

Hosmer and Lemeshow Test

\begin{tabular}{lcccc}
\hline Step & Chi-square & df & & \multicolumn{1}{c}{ Sig. } \\
\hline 1 & 13.227 & 8 & .104 \\
\hline Sumber : Data diolah, 2017 & & &
\end{tabular}

Kelayakan model regresi dinilai dengan menggunakan Uji Hosmer dan Lemeshow. Pengujian menunjukkan nilai Chi-square sebesar 13,227 dengan signifikansi sebesar 0,104. Berdasarkan hasil tersebut, karena nilai signifikansi lebih besar dari 0,05 maka dapat disimpulkan bahwa model dapat diterima karena cocok dengan data observasinya.

Tabel 4.

Nagelkerke R Square

\begin{tabular}{lrcrr}
\hline Step & $\mathbf{- 2 ~ L o g ~ l i k e l i h o o d}$ & $\begin{array}{c}\text { Cox \& Snell } \boldsymbol{R} \\
\text { Square }\end{array}$ & $\begin{array}{c}\text { Nagelkerke } \boldsymbol{R} \\
\text { Square }\end{array}$ \\
\hline 1 & $854.945^{\mathrm{a}}$ & .019 & .025 \\
\hline Sumber: Data diolah, 2017 & & & &
\end{tabular}

Pengujian dilakukan dengan membandingkan nilai antara -2 LogLikelihood $(-2 \mathrm{LL})$ pada awal $($ Block Number $=0)$ dengan nilai -2 Log Likelihood pada akhir ( Block Number $=1$ ). Hasil pengujian ditampilkan dalam tabel pada lampiran 3.Nilai -2LL awal adalah sebesar 866,746.Setelah dimasukkan keempat variabel independen, maka nilai -2LL akhir mengalami penurunan menjadi sebesar 854,954. Penurunan Likelihood (-2LL) ini menunjukkan model regresi 
Ni Luh Made Sutaryani dan Made Sadha Suardikha. Pengaruh...

yang baik atau dengan kata lain model yang dihipotesiskan fit dengan data.Besarnya nilai koefisien determinasi pada model regresi logistik ditunjukkan oleh nilai Nagelkerke $R$ Square.Nilai Nagelkerke $R$ Square adalah sebesar 0,025 yang berarti variabilitas variabel dependen yang dapat dijelaskan oleh variabel independen adalah sebesar 2,5 persen, sedangkan sisanya sebesar 97,5 persen dijelaskan oleh variabel-variabel lain diluar model penelitian.

Tabel 5.

Matriks korelasi

\begin{tabular}{crrrrrr}
\hline & & Constant & \multicolumn{2}{l}{ ROA } & OPM & \multicolumn{2}{l}{ LEV } & \multicolumn{2}{l}{ UP } \\
\hline Step 1 & Constant & 1 & -.044 & -.061 & -.212 & -.987 \\
& ROA & -.044 & 1 & .012 & .023 & .042 \\
& OPM & -.061 & .012 & 1 & .032 & .055 \\
& LEV & -.212 & .023 & .032 & 1 & .117 \\
& UP & -.987 & .042 & .055 & .117 & 1 \\
\hline
\end{tabular}

Sumber: Data diolah, 2017

Hasil pengujian menunjukkan tidak ada nilai koefisien korelasi antar variabel yang nilainya lebih besar dari 0,8 , maka dapat disimpulkan tidak terdapat gejala multikolinearitas yang serius antar variabel bebas. 
Tabel 6.

Tabel klasifikasi

Predicted

Perataan Laba

\begin{tabular}{llllr}
\cline { 3 - 4 } Observed & \multicolumn{1}{c}{$\begin{array}{c}\text { Tidak } \\
\text { melakukan } \\
\text { perataan laba }\end{array}$} & $\begin{array}{c}\text { Melakukan } \\
\text { perataan laba }\end{array}$ & Percentag \\
\hline Perataan laba & $\begin{array}{l}\text { Tidak melakukan } \\
\text { perataan laba }\end{array}$ & 45 & 235 & 16.1 \\
\cline { 2 - 5 } & $\begin{array}{l}\text { Melakukan } \\
\text { perataan laba }\end{array}$ & 41 & 310 & 88.3 \\
& & & & \\
\end{tabular}

Overall Percentage

Sumber: Data diolah, 2017

Tabel 6. menunjukkan bahwa kekuatan prediksi dari model regresi yang digunakan untuk memprediksi tidak melakukan perataan laba oleh perusahaan adalah sebesar 16,1 persen. Hal ini berarti bahwa dengan menggunakan model regresi yang diajukan terdapat 45sampel yang diprediksi tidak akan melakukan perataan laba dari total 86 sampelyang tidak melakukan perataan laba. Sedangkan, kekuatan prediksi model regresi untuk melakukan perataan labaadalah sebesar 88,3 persen, yang berarti bahwa dengan menggunakan model regresi yang diajukan terdapat 310 sampel yang diprediksi akan melakukan perataan laba dari total 545 sampel yang melakukan perataan laba. 
Tabel 7.

Variabel dalam persamaan

95\% C.I.for

$\operatorname{EXP}(\mathbf{B})$

\begin{tabular}{|c|c|c|c|c|c|c|c|c|c|}
\hline & & B & S.E. & Wald & df & Sig. & $\operatorname{Exp}(\mathbf{B})$ & Lower & Upper \\
\hline \multirow[t]{5}{*}{ Step $1^{\mathrm{a}}$} & ROA & -.006 & .004 & 2.222 & 1 & .136 & 994 & .986 & 1.002 \\
\hline & OPM & .003 & .011 & .065 & 1 & .798 & 1.003 & .981 & 1.025 \\
\hline & LEV & .111 & .098 & 1.278 & 1 & .258 & 1.117 & .922 & 1.354 \\
\hline & UP & -.106 & .044 & 5.864 & 1 & .015 & 900 & .826 & .980 \\
\hline & Constant & 1.616 & .621 & 6.775 & 1 & .009 & 5.032 & & \\
\hline
\end{tabular}

Sumber : Data diolah, 2017

Tabel 7. menunjukkan hasil pengujian dengan regresi logistik pada taraf kesalahan 5 persen. Hasil pengujian regresi logistik menghasilkan model sebagai berikut:

$$
\operatorname{Ln} \frac{I N S}{1-I N S}=1,616-0,006 R O A+0,003 O P M+0,111 L E V-0,106 U P
$$

Berdasarkan model regresi logistik yang terbentuk, dapat diinterpretasikan hasil variabelROAmenunjukkan koefisien regresi negatif sebesar 0,006 dengan tingkat signifikansi 0,136 yang lebih besar dari $\alpha$ (5\%). Jadi dapat disimpulkan perubahaan ROA secara signifikan tidak berpengaruh terhadap perataan laba. OPM menunjukan koefisien regresi positif sebesar 0,003 dengan tingkat signifikansi 0,798 yang lebih besar dari $\alpha(5 \%)$. Jadi dapat disimpulkan perubahaan OPM tidak berpengaruh terhadap Perataan laba.Variabel leverage menunjukan koefisien regresi positif sebesar 0,111 dengan tingkat signifikansi 0,258 yang lebih besar dari $\alpha(5 \%)$. Jadi dapat disimpulkan bahwa leverage tidak 
berpengaruh terhadapperataan laba.Variabel ukuran perusahaan menunjukan koefisien regresi negatif sebesar 0,106 dengan tingkat signifikansi 0,015 yang lebih kecil dari a (5\%). Jadi dapat disimpulkan bahwa ukuran perusahaan berpengaruh terhadap perataan laba.

Hasil pengujian dengan menggunakan regresi logistik menunjukkan koefisien regresi negatif sebesar 0,006 dengan tingkat signifikansi 0,136 yang lebih besar dari 0,05 sehingga $\mathrm{H}_{1}$ dapat ditolak dan $\mathrm{H}_{0}$ diterima. Hasil pengujian terhadap hipotesis tersebut diperoleh bukti empiris bahwa perubahaan ROA tidak berpengaruh terhadap perataan laba. Hasil penelitian ini mendukung hasil penelitian yang dilakukan oleh Ashari et, al (1994), Juniarti dan Corolina (2005), Syahriana (2006), dan Dewi (2011) tetapi tidak mendukung hasil penelitian yang dilakukan oleh Kumaladewi (2010), dan Budiasih (2009). ROA tidak berpengaruh terhadappraktik perataan labaoleh manajemen diduga karena para investor cenderung tidak menggunakan informasi ROA secara maksimal (Noor, 2004:77), sehingga manajemen tidak terlalu termotivasi untuk melakukan perataan laba melalui variable tersebut.

Hasil pengujian dengan menggunakan regresi logistik menunjukkan koefisien regresi negatif sebesar 0,003 dengan tingkat signifikansi 0,798 yang lebih besar dari 0,05 sehingga $\mathrm{H}_{1}$ dapat ditolak dan $\mathrm{H}_{0}$ diterima. Hasil pengujian terhadap hipotesis tersebut diperoleh bukti empiris bahwa perubahaan OPM tidak berpengaruh terhadap perataan laba. Hasil penelitian ini bertentangan dengan hasil penelitian yang dilakukan oleh Kumaladewi (2010) dan Syahriana (2006). 
Ni Luh Made Sutaryani dan Made Sadha Suardikha. Pengaruh...

Hasil pengujian dengan menggunakan regresi logistik menunjukkan koefisien regresi positif sebesar 0,111 dengan tingkat signifikansi 0,258 yang lebih besar dari 0,05 sehingga $\mathrm{H}_{1}$ dapat ditolak dan $\mathrm{H}_{0}$ diterima. Hasil pengujian terhadap hipotesis tersebut diperoleh bukti empiris bahwa leverage tidak berpengaruh terhadap perataan laba. Hasil penelitian ini mendukung hasil penelitian yang dilakukan oleh Dewi (2011), Budiasih (2009), dan Budhijono (2006), tetapi tidak mendukung hasil penelitian dari Ratih Kartika Dewi dan Zulaikha (2009). Hasil penelitian ini menunjukan rata - rata perusahaan yang menjadi sampel penelitian ini memiliki tingkat utang yang tidakbegitu tinggi atau perusahaan tidak bergantung pada utang dalam membiayai aktiva (Ratih Kartika Dewi dan Zulaikha, 2009).Hasil pengujian dengan menggunakan regresi logistik menunjukkan koefisien regresi negatif sebesar 0,106 dengan tingkat signifikansi 0,015 yang lebih besar dari 0,05 sehingga $\mathrm{H}_{1}$ diterima. Arah koefisien regresi ukuran perusahaan memiliki nilai negatif hal tersebut menunjukan perusahaan dengan total aktiva yang lebih kecil cenderung untuk melakukan perataan laba. perusahaan yang berukuran kecil akan lebih cenderung untuk melakukan praktik perataan laba dibandingkan dengan perusahaan besar, karena perusahaan besar cenderung mendapatkan perhatian yang lebih besar dari analisis dan investor dibandingkan perusahaan kecil (Noor, 2004:32).

Hasil pengujian terhadap hipotesis tersebut diperoleh bukti empiris bahwa ukuran perusahaan berpengaruh terhadap perataan laba. Hasil penelitian ini mendukung hasil penelitian yang dilakukan oleh Dewi (2011), Budiasih (2009), Budhijono (2006), dan Ashari et, al (1994) tetapi tidak mendukung hasil 
penelitian dari Kumaladewi (2010), Juniarti dan Corolina (2005), dan Ratih Kartika Dewi dan Zulaikha (2009).

\section{SIMPULAN}

Berdasarkan analisis data dan pembahasan yang telah dilakukan, dapat diambil kesimpulan sebagai berikut, ROA, OPM, dan Leverage tidak berpengaruh pada praktik Perataan laba pada perusahaan manufaktur yang terdaftar diBursa Efek Indonesia. Sedangkan ukuran perusahaan berpengaruh secara signifikan pada praktik perataan laba.

Hasil uji koefisien determinasi (Nagelkerke $R^{2}$ ) penelitian ini, yaitu sebesar 2,5 persen variabilitas variabel dependen dapat dijelaskan oleh variabel independen. Masih sebesar 97,5 persen dapat dijelaskan oleh variabel independen lain diluar model penelitian yang dilakukan. Sehingga saran yang dapat diberikan adalah dengan memasukkan variabel lain yang secara teoritis mungkin dapat mempengaruhi perataan laba, seperti menambahkan variabel rasio-rasio keuangan yang lainnya seperti rasio profitabilitas, rasio likuiditas, selain itu juga dapat menambahkan variabel non keuangan seperti, asimetri informasi, dan menggunakan tahun amatan yang lebih banyak.

Penelitian ini hanya dilakukan pada perusahaan manufaktur, akan menjadi lebih baik apabila pada penelitian selanjutnya menggunakan seluruh perusahaan di Bursa Efek Indonesia (BEI) dengan mempertimbangkan kriteria pengambilan sampel yang sesuai atau menggunakan perusahaan sektor lainnya. Pada penelitian ini hanya membahas satu jenis manajemen laba yaitu perataan laba.Diharapkan 
Ni Luh Made Sutaryani dan Made Sadha Suardikha. Pengaruh...

pada penelitian selanjutnya juga membahas jenis manajemen laba lainnya atau manajemen laba secara keseluruhan.

\section{REFERENSI}

Abdullah M Faisal. 2005.Dasar-dasar manajemen keuangan. Cetakan Kelima. Malang: Universitas Muhamadiyah Malang.

Ashari, et al. 1994. 'Factor affecting income smoothing among listed companies in singapore,' Accounting Businees Research.

Bambang, Riyanto, 2001. Dasar-dasar pembelanjaan perusahaan, Edisi Keempat, Cetakan Ketujuh, Yogyakarta, BPFE Yogyakarta.

Budiasih, I G A N. 2009. 'Faktor-faktor yang mempengaruhi praktik perataan laba'.AUDI Jurnal Akuntansi dan Bisnis, 4 (1), Januari 2009, h:44-50.

Brigham, Eugene dan Joel F Houston, 2001. Manajemen keuangan II. Jakarta:Salemba Empat

Ghozali, Imam. 2011. Aplikasi analisis multivariate dengan program SPSS. Semarang: Badan Penerbit Universitas Diponegoro.

Halim, Prof. Dr. Halim, M.B.A., Akt dan Dr. Mamduh M. Hanafi, M.B.A.."'Analisis Laporan Keuangan "

Jatiningrum. 2000. "Analisis Faktor-faktor yang Berpengaruh terhadap Perataan Penghasilan atau Laba pada Perusahaan yang Terdaftar di BEJ". Jurnal Bisnis dan Akuntansi. 2 (2), h : 145 - 155.

Jin, Liaw She dan Mas'ud Machfoedz. 1998. "Faktor-faktor yang Mempengaruhi Praktik Perataan Laba pada Perusahaan yang Terdaftar di Bursa Efek Jakarta”. Jurnal Riset Akuntansi Indonesia. Vol. 1 (2). hal 174-191.

Juniarti dan Corolina. 2005. "Analisa Faktor-faktor yang Berpengaruh terhadap Perataan Laba (Income Smoothing) pada Perusahaan GoPublic". Jurnal Akuntansi dan Keuangan. Vol. 7(2).h: 148 - 162.

Kumaladewi, Patricia Ratna.2010.'’Pengaruh Perubahan Return On Asset, Perubahan Operating Profit Margin, dan ukuran perusahaan terhadap kemungkinan praktik perataan laba pada perusahaan manufaktur yang terdaftar di bursa efek indonesia".Jurnal akuntansi dan Bisnis. Vol. 5(2).h: $184-195$. 
Noor, Y.M. (2004). "Faktor-Faktor yang Mempengaruhi Praktik Perataan Penghasilan Bersihpada Lembaga Keuangan yang terdaftar pada BEJ." Skripsi, Fakultas Ekonomi Jurusan Akuntansi Universitas AirlangaSurabaya.

Sugiyono. 2007. Metode Penelitian Bisnis. Bandung: Alfabeta.

Suwito dan Herawaty. 2005. 'Analisis Pengaruh Karakteristik Perusahaan terhadap Tindakan Perataan Laba yang dilakukan oleh Perusahaan yang Terdaftar di Bursa Efek Jakarta'.SNA VIII Solo. September.

Wiagustini, Ni luh Putu. 2010. Dasar - Dasar Manajemen Keuangan. Denpasar.Udayana University Press.

Watts, Ross L. and Jerold L. Zimmerman. 1986. Positive Accounting Theory. New Jersey: Prentice Hall International Inc. 